\title{
SABLOT (LITSEA GLUTINOSA), LOUR ROB., IN THE CONTINUING PRESERVATION AND CONSERVATION OF THE CULTURAL HERITAGE OF ILOCOS (PHILIPPINES)
}

\author{
Norma A. Esguerra \\ College of Engineering, University of Northern Philippines \\ Vigan City, 2700 Ilocos Sur, Philippines \\ jafbkc@yahoo.com
}

\begin{abstract}
The ethical guideline that appropriate materials be used for the conservation and preservation of cultural heritage implies that the original set of materials be used, thus, the need to replicate the same materials used by the forefathers. This study then promotes the use of sablot, (Litsea Glutinosa), Lour Rob., a native Philippine tree, in the conservation and preservation of the heritage structures of Ilocos, Philippines, and demonstrates the structural feasibility of sablot paste as cement substitute. Historical and technical approaches were used to develop the research. By historical approach, documentary analysis of information was conducted among selected structures to present the facts about the time of construction and methods used by the Ilocano builders. Records show that the churches of Ilocos were constructed earlier than the recorded date of invention of cement in 1824 by Joseph Aspdin, an English inventor. Interviews with selected elderlies knowledgeable of the construction methods were conducted to determine the proportion of the aggregates and the sablot paste. From the interviews, the technical approach followed, where samples were constructed to replicate the proportion of the original formulation of the sablot paste and aggregates. In conclusion, the Ilocos churches testify to the capability of the sablot solution to bind the construction aggregates used during the pre-cement era.The sablot paste is as strong as cement within ordinary loadings, and the age of the sablot paste has a significant effect to its strength.
\end{abstract}

Keywords: Sablot, sablot paste, preservation, conservation, heritage

\section{Introduction}

On December 21, 1999, Vigan, then and up to now, the capital town of Ilocos Sur, became a UNESCO-inscribed heritage site. As such, the local government has to preserve and conserve its culture which is composed of tradition, as well as its existing structures by virtue of a Memorandum of Agreement with the Government of the Republic of the Philippines, through the Department of Tourism, and the Government of Spain, through the Agencia Española Cooperacion Internacional, the Presidential Commission for the Restoration, Conversion and Preservation of the Vigan
Heritage Village.

(http://tawidnewsmag.com/ Tawid News Team, February 26, 2007). These agencies came together and crafted the Vigan Masterplan.

The Cultural Heritage Act of 2009 or Republic Act 10066 of the Republic of the Philippines, defines cultural heritage as the totality of cultural property preserved and developed through time and passed on to posterity.https://www.heritage.org.ph/. The Heritage Conservation Council is commissioned by the Philippine Government for the above mandate. It entails the processes and measures of 
maintaining the cultural significance of a cultural property, including but not limited to the preservation, restoration, reconstruction, protection, or combinations of the mentioned processes. However, the Council is only interested to the built environment, which are the architectural and engineering structures.

The work of Anna Marie Sullivan (Sullivan, 2016) published in the Encyclopaedia of Conservation and Restoration points out that conservation-restoration of cultural heritage focuses on the protection and care of tangible cultural heritage, including artworks, architecture, archaeology, and museum collections.

An older author describes restoration as the sustained goal to savor a work of art and to appreciate its material form, together with its historical and aesthetic duality, with a view of transmitting it to the future". Conservation of cultural heritage is concerned with the collection of works of art, establishment of museums including the care and management of these collections through tracking, examination, documentation, exhibition, storage, preventative conservation, and restoration (Szczepanowska, 2013). This is also expressed in the American Institute for Conservation of Historic and Artistic Works (AIC) Preamble, that the primary goal of conservation is for the preservation of cultural property, which may consist of individual objects, structures, or aggregate collections. It is material which has significance that may be artistic, historical, scientific, religious, or social, and it is an invaluable and irreplaceable legacy that must be preserved for future generations.In striving to achieve this goal, conservation professionals assume certain obligations to the cultural property, to its owners and custodians, to the conservation profession, and to society as a whole. This document, the Code of Ethics and Guidelines for Practice of the American Institute for Conservation of Historic \& Artistic Works (AIC), sets forth the principles that guide conservation professionals and others who are involved in the care of cultural property.

The conservation-restoration program of the City Government of Viganhas widened from art conservation, to the protection and care of artworks and architecture, also including protection and care of a broad set of other cultural and historical works. The Conservation of cultural heritage can be looked at as a type of ethical stewardship in the sense that it embodies the responsible planning and management of resources. The concepts of stewardship can be applied to the environment and nature, (Stuart, et al, 2009), economics, (Curtis, 2012) health, (Robinson, et al, 2012),information, (National Academies Press, 2009), theology, (Van Dyke, 2008). In business, stewardship advances the concept that "as a steward, you try to leave the company in better shape for your successor than it was handed over to you by your predecessor (Jean-Pierre \& Schreuder. 2015).The definition of the International Standardization for Organizations (ISO 20121) states that: Event sustainability management system Requirements with guidance for use; par. 3.20: "responsibility for sustainable development shared by all those whose actions affect environmental performance, economic activity, and social progress, reflected as both a value and a practice by individuals, organizations, communities, and competent authorities."https://en.wikipedia.org/wiki/Co nservation-restoration_of cultural heritage.

Further, conservation and preservation programs apply ethical guidelines. These refer to the basic principle to govern the decision as to what methodology is accepted in implementing conservation and preservation programs. The ethical guidelines being used are: a) the use of minimal intervention, b) appropriate materials and reversible methods and c) full documentation of the work. Ethical standards have been established across the world, and national and international ethical guidelines have been written. One of such is the American Institute for the Conservation of Historical and Artistic Works (AIC) Code of Ethics.

Use of minimal intervention requires the use of simple, economical methods. Use of appropriate materials and reversible methods employ genuine conservation materials, not the "look-alike" strategy, which entails the use of original materials or methods used 
before. This guiding principle (also called reversibility) is the ability to return a work of art to its normal state prior to the conservation intervention. This concept remains still the guiding principle of conservation amidst the criticism of many, probably due to practical reasons, that materials used before may no longer be available at this present time. Another important principle of conservation is that all alterations should be well documented and should be clearly distinguishable from the original object (ICOM-CC International Council of Museums Committee for Conservation).

Full documentation of the work means that every action done be recorded, saved in print or non-print devices for replicability and/or sustainability of the adopted conservation technology. The AIC explicitly enumerates the following purposes of documentation as part of the undertakings of cultural heritage sustainability strategy; namely a) to establish the condition of cultural property; b) to aid in the care of cultural property by providing information helpful to future treatment and by adding to the profession's body of knowledge; c) to aid the owner, custodian, or authorized agent and society as a whole in the appreciation and use of cultural property by increasing understanding of an object's aesthetic, conceptual, and physical characteristics; and d) to aid the conservation professional by providing a reference that can assist in the continued development of knowledge and by supplying records that can help avoid misunderstanding and unnecessary litigation. In so doing, employing heritage conservation and preservation programs reduce the rate of deterioration of a collected work of art which is considered a memorabilia to contain history. Conservation professionals may use various methodologies to pursue this goal which may be for aesthetics, stabilization needs for structural integrity or cultural requirements for intangible continuity. Examples of such methodologies may be the removal of discolored varnish from a painting, the application of wax to a sculpture, or the washing and rebinding of a book. Ethical standards within the field require that the conservator fully justify conservation actions and carry out documentation before, during, and after the treatment.

This study tries to focus on appropriate materials as one ethical guideline to implement preservation and conservation of cultural heritage. It advocates for the use of genuine materials to perpetuate preservation and conservation of the Ilocos Heritage buried in the built environment- the houses, the monuments, the churches, and all other constructs which reveal the culture and history of Vigan's rich and glorious past. However, the act of preservation and conservation may be done using the materials of today's technology, or by the same materials present before. If today's technology will be used, the method of preservation and conservation shall be with the use of cement with its sand and gravel combination for dilapidated brick walls, and similar items. If the genuine preservation and conservation shall be adopted, then, the original material make-up of the structures should be used, which were sablot ((Litsea Glutinosa), molasses and lime, to paste bricks together.

Sablot, being one of the main construction materials of yesteryears, is one of native Philippine trees listed in forestry accounts by the Forest Products Research and Development Institute (FPRDI) - one of the research arms or departments under the Department of Science and Technology, located at the upper campus of the University of the Philippines-Los Baños, at Los Baños, Laguna, Philippines. This body provides other data about structural timber needed in the design and construction of timber structures. The compilation of data on structural timber as a result of FPRDI's expertise is embodied in Chapter 6 of the National Structural Code of the Philippines. (https://www.pinterest.co.uk/nitoteves/philip pinenative-trees/?lp=true).Sablotis also one of the many useful trees which have aroused the interest of many foresters, scientists, and the like, because of its contents. The studies of Esguerra (2013) found out that sablot's leaves when soaked in water for three to five days, then used to mix with sand and lime, could turn the aggregates into a fluid mixture, similar to the concrete mixture nowadays with the sablot paste as the 
binder. The compressive stress of the samples constructed did not have significant difference with the samples made using cement as binder. Thus, sablot paste could be a substitute for cement. Having been considered as a vanishing species of trees, Rabena (2010) conducted a propagation technique for sablot.

The AIC through its Research and Technical Studies group, also supports those who are involved in research within the conservation field, and to help promote and advance scientific efforts in conservation. The presence of research undertakings also foster increased interaction and communication between conservators and scientists of all disciplines relevant to conservation. Tutur Lussetyowati (2015) conducted a case study on the Musi Riverside Palembang, Indonesia, where preservation and conservation of cultural heritage was realized through tourism. Thestudy linked tourism with heritage and culture, and found out that it benefited the local economy. The main idea in cultural heritage tourism which was to save urban heritage and culture, to share it with visitors, and to reach economic benefits was realized.

The study of Gunlu, et al (2015) with the same concept of cultural preservation and More related literature have been read about the binding systems from history. The simplest, and possibly the earliest, binding material used was wet mud, and there arerecords of its use in ancient Egypt. Another example of a binder from the distant past was the useof naturally occurring bitumen by the Babylonians and Assyrians in their brick and alabaster(gypsum plaster) constructions. https://knowledgepoint.org/upfiles/1427893 6733462015.pdf.Lime-pozzolan mixture have been the major types of binding materials which have survived indifferent regions ofthe world for 8000 years. However, no mention was made about the natural binder, sablot (Litsea Glutinosa) of Ilocandia (Philippines) described in this paper. The binder has survived almost six centuries basing from those who started the construction in the $15^{\text {th }}$ century, as the churches are still structurally fit up to this writing. tourism as a tool for regional development in Izmir corroborated with the findings of Tutur.The practical implication of this study is pointing out the possible policies and necessity of cooperation between the government and private sector in Izmir, being the most populated andthe most industrialized city, which plays a great role in the development of the AegeanRegion. Alivizatou (2016) aimed to centre cultural heritage studies within a wider concern for the preservation of humandignity and justice and to use these alternative discourses as a resource for future action, therebycreating a proactive, responsive and just future for cultural heritage studies. In a Philippine setting, Ueno (2014) found out that there is lack of human resources to safeguard cultural heritage. This is attributed to lack of human resource development and training institutions along this line. $\mathrm{He}$ further commented in his report that the situation involving cultural heritage in the Philippines and its protection is extensive with questions. Dela Paz (2015) conducted a literature review on protection of built heritage. He said that protecting the built heritage relies on an organized, systematic and integrated outline involving extensive research, documentation, analysis, and reporting of the various aspects of the building artefact being studied.

Among construction materials, their exposure on water has been a standard operating procedure of handling them. They may have strong, mild or no effect at all when soaked in water. The following studies would reinforce the researcher's purpose when her investigation also used soaking to discover more information about her subject matter. Li, et al (2009) conducted the effect of soaking medium density fibreboard (MDF) in soybean protein, a renewable and abundant material that offers an alternative to formaldehyde-based resins. The study traced strong relationships between mechanical and soaking properties of MDF and processing parameters. Properties of MDF made using soybean protein adhesive are similar to those of commercial board.

On the other hand, Ruså-Lie (2015) also studied the effect of soaking at two hardening temperatures on material properties and morphology for the 
martensitic ferritic steel S165M. He found that $\mathrm{S} 165 \mathrm{M}$ is a remarkably resistant alloy, producing consistent qualities regardless of the soaking time and/or the hardening temperature.

Having convinced of the uniqueness of this organic matter used prior to the introduction of the present popularly developed cement, the researcher is more determined to offer a genuine act of preservation and conservation by using the original binder of bricks, sand and lime; the sablot. The role of sablot, through a historic and technical approach, should be appreciated as it has once shaped the cultural heritage of Ilocandia, buried in its antique, baroque churches and structures. Further, this study also aims to substantiate binding characteristics of sablot unexplained by the forefathers through initial, experimental studies to perpetuate its legacy in the conservation and preservation of the cultural heritage of Ilocandia, the land of frugal and caringIlocanos of Northern Philippines. This part of the research conforms to the Commentary of the AIC which states that using materials and methods that are consistent with currently accepted practice will help the conservation professional to avoid the adoption of insufficiently tested materials and methods and to determine whether the use of existing materials and methods is appropriate in new treatment situations. Materials and methods become recognized as currently accepted practice through appropriate testing and publication in peer-reviewed literature. This process provides an understanding of the characteristics and properties of the materials and methods, especially their aging properties.

Materials and methods become part of currently accepted practice through:

a) replicable research;

b) objective review of past practices;

c) professional consultation and open discussion at professional meetings;

d) industrial information (e.g., ASTM, ANSI); and

e) publication in peer-reviewed literature.

The AIC guideline further states that where the wholesale application of a material or method to cultural property is contemplated, testing must be conducted on a small, unobtrusive section of the cultural property, or on mock-ups. Representative samples of original material of the cultural property removed during treatment must be retained with the cultural property, in a file, or with the owner/custodian. This part was also undertaken in this study.

\section{Method}

The researcher used the historical and experimental methods of research to undertake the study. It is reiterated that AIC Code of Ethics favours the conduct of researches in aid of cultural heritage preservation and conservation, from which this undertaking based its legitimate conduct. The historical part was used to recount the use of sablot (Litsea glutinosa) when it was used as binder for bricks and as a plaster to cover the brick surface over the centuries prior to the cement age. It was presented through documentation and interview to capture the cultural essence of the indigenous material. Pictures of the chosen churches are presented, most of which were inscribed in the UNESCO World heritage list.

The technical approach to this research utilized the conduct of experiments to reconstitute the sablot paste based from the interviews with Ilocano elderlies. Through this, the researcher was able to formulate a first-hand experience withthe sablot paste described from the interviews. Three (3) samples with sablot paste were extracted from a demolished antique fence. Their strength, measured by the ultimate compressive stress, fc', were compared with the ultimate compressive strength of hollow blocks today. Three (3) cylindrical concrete samples, 6 inches (150 millimeters $)$ in diameter, 12 inches (300 millimeters) long, were prepared to compare how sablot fares with the same size as the concrete cylinders. The sablot samples, aside from comparing their strength with concrete, were also intended to determine the effect of the length of soaking time on their strength: five (5) samples (Group A) with the sablot paste three (3) days old, and five (5) samples (Group B) with the sablot paste six (6) days old. The age of the sablot paste is the duration of its soaking time in water. 


\section{Results and Discussion}

The procedures discussed earlier yielded the following findings:

\subsection{The Historical Approach}

The Paoay Church

The Paoay Church is one testimony of the use of sablot as binder. Started in 1704, and inaugurated in 1896 (192 years in the making), the Spanish friars supervised the construction. (Vigan museum).

\section{Sta. Maria Parish Church}

Msgr. Roque Reyes, Parish Priest of the Conversion of St Paul Parish, Vigan City, Ilo-cos Sur during the conduct of this research, and Archdiocesan Curator of Nueva Segovia, also attested that the sablot leaves soaked in water develop a sticky substance that blends well with the aggregates for grouting and plastering. He has witnessed the sablot paste in the repair of the Sta. Maria Church where he was once the parish priest. The Sta Maria church is one of UNESCO's enlisted World Heritage Sites - a baroque church. He further attested that twenty one (21) churches of Ilocos Sur

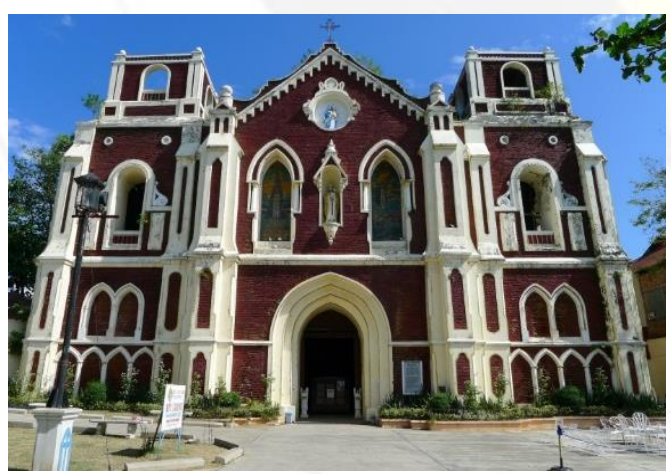

Figure 3. St. Augustine Church of Bantay, Ilocos Sur

were built using the sablot as binder.In the same interview with Mgsr. Reyes, the parish priest of Vigan during the conduct of this study, he claimed to have witnessed the repair of Sta. Maria church where he was also a parish priest. According to him, the binding capability of sablot reveals that the soaking period would take 3 to 7 days in big earthen jars at 5-8 cu ft capacity (burnays in
Iloko). The leaves were stored inside the jars, half-filled with water. The sablot solution would be taken out from the burnays to mix with the sand and lime aggregates. A proportion was followed for uniformity: two parts sand, one part lime, 1 part barisangsang, or unprocessed sugar. If not enough, the water component would again be replenished as the original amount in the same duration before it could bind again. This was done for two to three times at most, depending upon the state of the leaves' decomposition. Almost all of the churches in Ilocos Sur and Ilocos Norte were built using sablot paste as binder for bricks. Thick masonry walls ranging from $1.0 \mathrm{~m}$ to $1.5 \mathrm{~m}$ define the periphery of the structures.

\section{Bantay Parish Church}

St. Augustine Church, the Parish Church of Bantay, Ilocos Sur, was constructed in 1590.

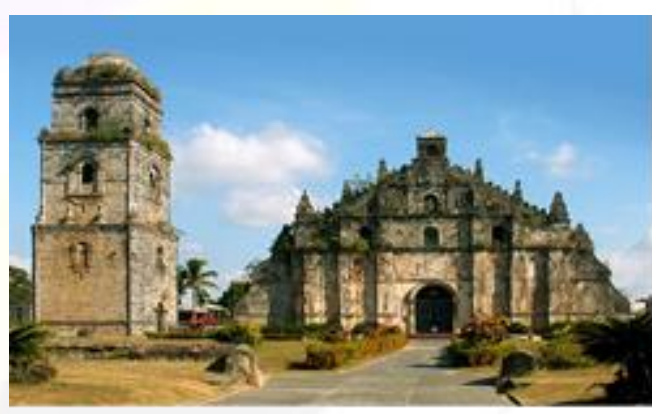

Figure 1. The Paoay (Ilocos Norte) church, one of the old churches constructed using the sablot solution as binder.

Vigan Cathedral and Belltower

According to testimonies of popular local aficionados in preservation and conservation led by Archt Rey Florentino in 2000, he well documented that sablot leaves were used as binder together with lime and the aggregates in the construction of big structures in the Ilocos, including that of the St. Paul Metropolitan Cathedral, renovated in the early 1900 š. 


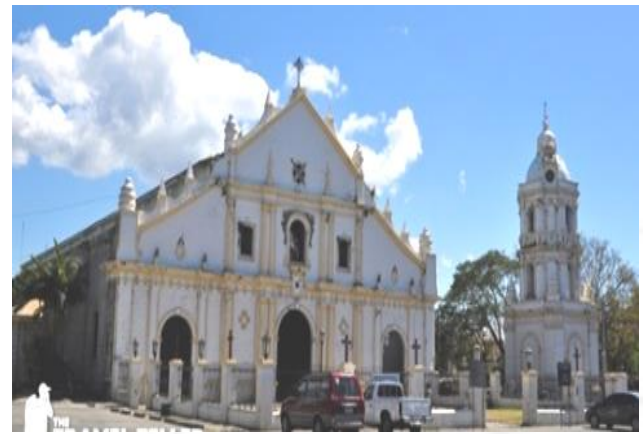

Figure 4. St. Paul Cathedral of Vigan City, built from 1786 to 1790.

San Juan (Ilocos Sur) Parish Church

Some selected senior citizens and elderlies of Ilocos Sur, confirm that sablot was used in the Ilocos Region as binder in building antique structures, particularly the churches which still stand today. They claim that centuries ago, old Ilocano builders used the solution where sablot leaves were soaked for days stored in old earthen jars called burnays, to bind bricks, sand, sugar and lime for grouting, then in plastering the bricks.

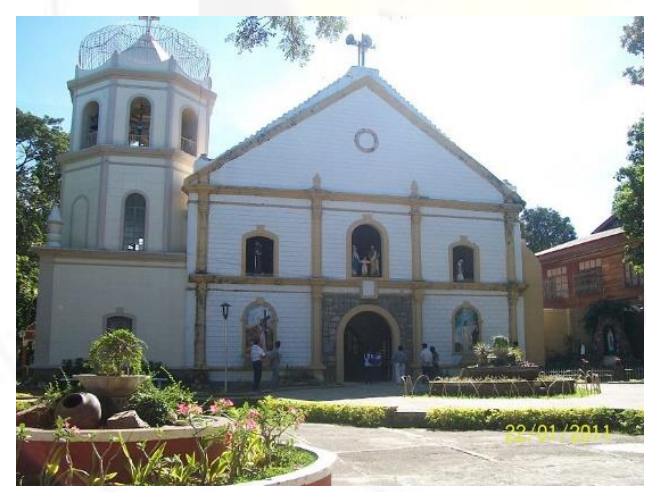

Figure 5. St. John, the Baptist Church of San Juan, Ilocos Sur, was built in 1641

\section{Laoag City Cathedral}

The first church was made of wood constructed in 1580 by the Augustinian friars when the parish was established but was damaged by fire. It was re-constructed in 1612 with its present foundation of massive bricks, binded by the same construction materials like its neighboring churches.

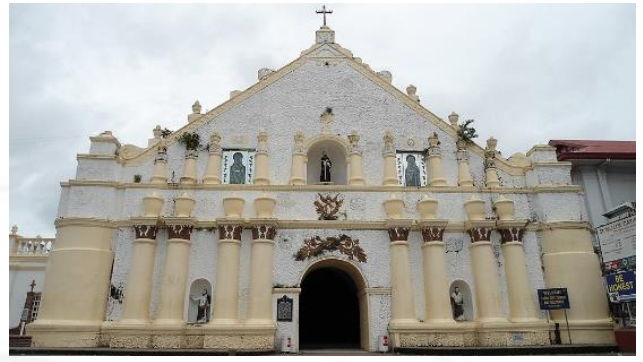

Figure 6. St. William Cathedral of Laoag City, built in 1612.

\section{Badoc Church}

The same testimonies speak of the similarities in the physical make up of the Badoc Church with its neighboring churches. The Badoc Church is under the matronage of Our Lady Cause of Joy.

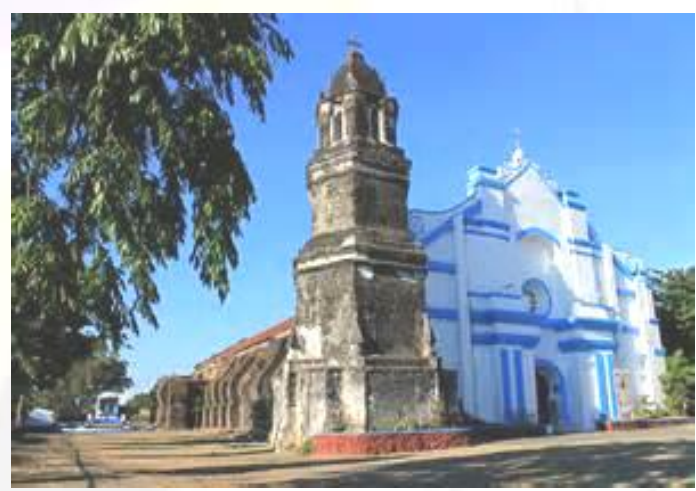

Figure 7. Our Lady Cause of Our Joy Church of Badoc, Ilocos Norte, built in 1714.

\section{Sinait Parish Church}

Indigenous materials were used for the construction. Coral bricks made of sticky clay and molasses mixed with leaves and tree trunks of a tree soaked in water or "sablot" were used instead of cement, granite or adobe stones. The mixture resulted in a sticky fluid which was then combined with lime from ashes of burnt shells. The bricks were pieced together with stucco, the mixture beaten to paste. All the labor was manual. http://www.philippinesmyphilippines.wordp ress) 


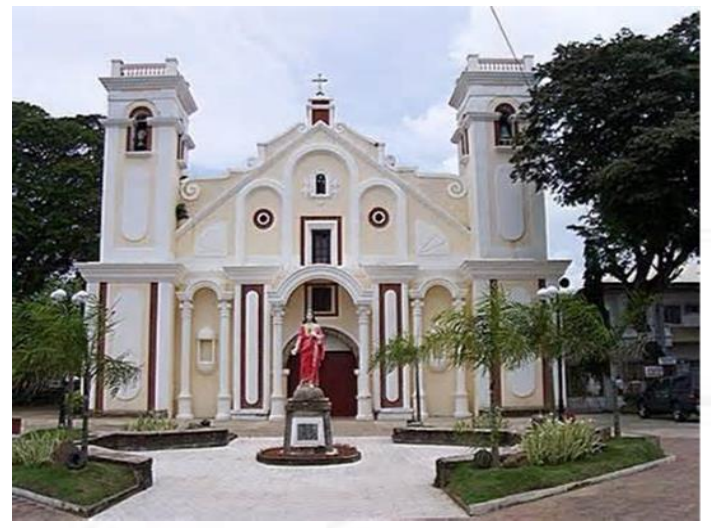

Figure 8. San Nicolas de Tolentino Parish, Sinait, Ilocos Sur, the Shrine of Apo Lakay, the Crucified Jesus, was built of corals, woven together using sablot, sand and lime.

\section{Candon Church}

Similarly, the Candon Church was also made of the samematerials like the churches of other towns using sablot as the binder.

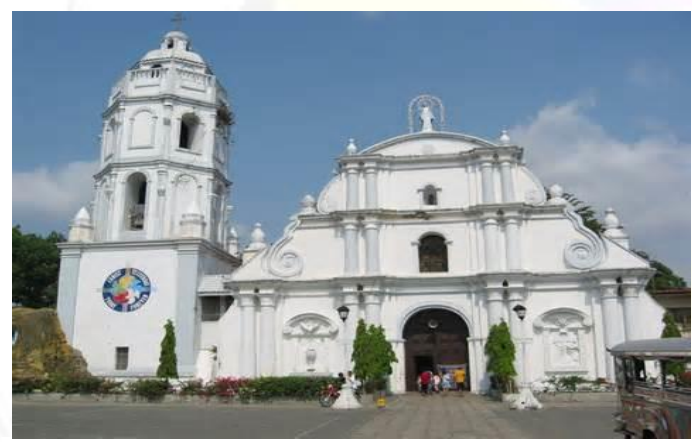

Figure 9. St. John de Sahagun Church of Candon City, Ilocos Sur was built in 1695, rebuilt in 1709

\section{Sarrat Church}

The Roman Catholic Church of Sarrat, dedicated to the matronage of Santa Monica is located in Barangay San Leandro, Poblacion, Sarrat, Ilocos Norte, Philippines (Dela Torre, 2006). It was built in 1779 and was originally known as San Miguel Church. The Santa Monica Church complex includes the convent connected to the church by an elevated three-level brick stairway. Sarrat Church is the biggest in Ilocos Norte and possibly in the whole Ilocos region. The church is made from red bricks built in
Earthquake Baroque and Neoclassical architecture.

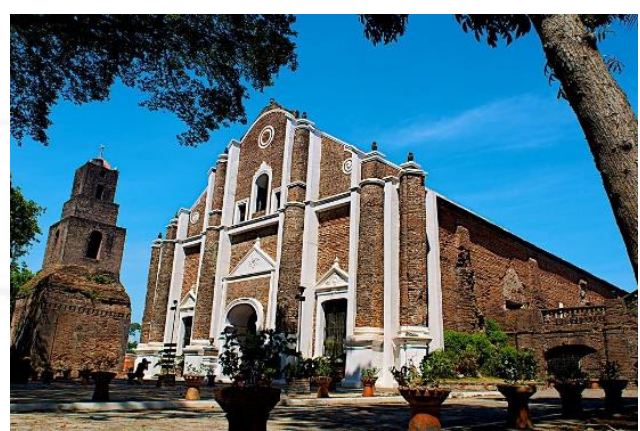

Figure 10. The Sta Monica Parish Church of Sarrat, Ilocos Norte was built in 1779

Among the antique churches shown, no one of them was constructed earlier than 1824, the year when Joseph Aspdin introduced cement to the world.

\subsection{The Technical Approach}

The technical approach used the experimental method of research. The composition of the sablot paste so described in the interviews was reconstituted and subjected to compressive strength tests so as to establish some first hand information about the construction material of the 16th century.

In Table 1, three sablot samples were extracted from an old fence, and they represent original sablot mixtures, while the concrete samples represent modern structures.

Table 1: Compressive Stress, Fc' Values of Samples in MPa, using Sablot and Cement

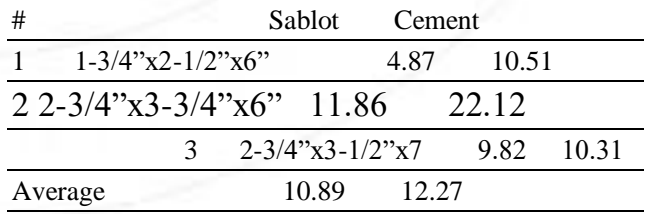

The concrete cylinders paired with the debris samples were molded from ungraded mixed aggregates hauled from the riverbanks of Banaoang Santa, Ilocos Sur which is one of the most accessible hauling site. This should explain why the compressive stress results were low in contrast to the lowest fc' used for concrete 
which is $17 \mathrm{MPa}$. The use of ungraded mixed aggregates was used to capture country-side construction which usually use ungraded mixed aggregates to make small bungalows or one-storey residential houses.

When the strengths of the samples made of sablot paste were compared to the strength of the concrete samples, a t-value of 0.267 was computed which is less than the significant value of 0.802 , making it not significant. This suggests that the fc' values of the samples out of sablot paste are as strong as those of cement.

Table 2 shows the strengths in terms of the ultimate compressive stresses of the samples mixed by the 3-day old sablot paste

Table 2. Compressive Strength of Samples with 3 days soaking time (Group A)

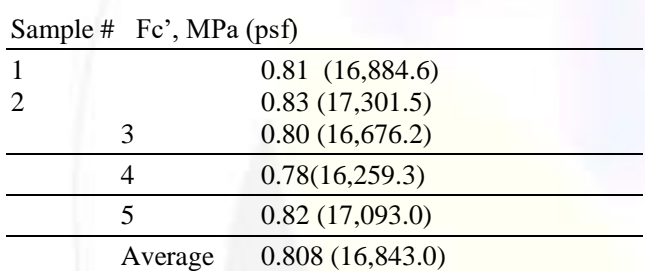

Table 3 similarly reveals the strengths measured in terms of the ultimate compressive stress of the samples mixed with 6-day old sablot paste.

Table 3. Compressive Strength of Samples with 6 days soaking time (Group B)

\begin{tabular}{|c|c|}
\hline \multicolumn{2}{|c|}{ Sample \# } \\
\hline 1 & $0.95(19,802.9)$ \\
\hline 2 & $0.90(18,760.7)$ \\
\hline 3 & $0.94(19,594.5)$ \\
\hline 4 & $0.93(19,386.0)$ \\
\hline 5 & $0.91(18,969.0)$ \\
\hline & $0.926(19,302.7)$ \\
\hline
\end{tabular}

The results of the compressive tests show that the samples in Group B resisted relatively higher stresses than those in Group A. Apparently, the length of soaking time affects the strength of the resulting mixture.

The samples of Group B were 244 days old. The sablot paste where the leaves were soaked in clean water was six (6) days old. When the fc' values of the two groups of samples using the soaking time of 3 days and 6 days as variable were analyzed, the tvalue computed $(\mathrm{t}=-9.329)$ was less than the significant value of $t$ at .000 . Therefore, the soaking time is significant.

This further suggests that the soaking time affects the strength of the samples. The samples in Group B molded using the sablot paste six (6) days old are stronger than those samples molded with sablot paste three (3) days old. It was observed further during the experiment that in three-day time, the leaves soaked in water started to exude white sticky substances called latex. This reaction with water last only for seven (7) days, since all the latex are dissolved as the leaves start to disintegrate. The most sticky sablot paste occurred from the 3rd to the 6th day. When mixed with sand and lime the resulting mixture became fluid and plastic, similar in appearance and manageability as the present-day concrete mixture. After the 7 th day, the sablot solution loses its binding power.

\section{a. Economics of the Sablot Paste}

A practical financial analysis has been conducted to convince the potential taker of this proposed technology. Being affordable and readily available are two of the major considerations in endorsing the sablot to solve housing problems for the rural poor. The proponent came up with the findings presented subsequently. A one square meter wall panel is taken as the subject of comparison. Its thickness is set to be uniform at one inch on both sides, internally and externally. The proportion of the concrete plaster and its area of coverage shall also be the wall coverage of the plaster using sablot as binder. The volume per mix is 0.085 cu.m. The coverage area for this volume of plaster is 1.8 sq.m. The sablot paste contains one part lime and two parts sand, practically yielding the same volume of mixture as the cement plaster and the same coverage of plastered area.

The cement plaster uses an approximate volume of 25-30 liters of water to mix the aggregates for every bag of cement. The same volume of water is also the same volume of sablot solution needed to mix the 
aggregates in the preparation of the sablot plaster.

By comparing estimates with the cement and sablot plaster, (refer to Table 4) the cement plaster incurs a total expenditure of P 264 for every one square meter of area plastered, while the sablot plaster only incurs a minimum expense of P171.50 for the same area, using current market prices during the conduct of this research.

Table 4. Comparative Estimate on the Use of Cement and Sablot as Wall Plaster

\begin{tabular}{c|c|c|c|c} 
Qty & $\begin{array}{c}\text { Unit } \\
\text { Cost }\end{array}$ & $\begin{array}{c}\text { Cement } \\
\text { Plaster } \\
\text { Compo- } \\
\text { nents }\end{array}$ & $\begin{array}{c}\text { Unit of } \\
\text { Measure }\end{array}$ & Total \\
\hline 1 & 230 & $\begin{array}{c}\text { Portland } \\
\text { Cement }\end{array}$ & bag & 230 \\
\hline 0.05 & 600 & River Sand & Cu,m, & 34 \\
\hline 7 & & Total & 264 \\
\hline Qty & Unit & $\begin{array}{c}\text { Sablot } \\
\text { Plaster } \\
\text { Compo- } \\
\text { nents }\end{array}$ & $\begin{array}{c}\text { Unit of } \\
\text { Measure }\end{array}$ & Total \\
\hline 0.5 & 275 & Lime & Bag & 137 \\
\hline 0.05 & 600 & $\begin{array}{c}\text { River Sand } \\
7\end{array}$ & Cu.m. & 34 \\
\hline & & & & 171.50
\end{tabular}

\section{Conclusion}

The Ilocos churches are testimonies of the capability of the sablot solution to bind the construction aggregates used during the precement era. The research conducted about the binding technology using lime from the study of O. Kirka (2005) documented that the structures built using the ancient binder has lasted for 8000 years. The natural binder used in Ilocos has survived for barely six centuries or 600 years already, in as far as documents reveal, which is already comparably effective, since this binder is an organic matter. Therefore, its use could be continued and adopted, to carry on a genuine preservation and conservation of the heritage structures. Efforts for its propagation should already be targeted to facilitate its reproduction as an assurance to its availability. One method of reproduction was discussed in the research of Tiwari, et al: 2015.
In view of the findings solicited from the study, the experiments conducted suggest that: a) the sablot paste is as strong as cement within ordinary loadings, and b) the age of the sablot paste has a significant effect to its strength. Likewise, like the studies of Li, et al, Rusa-lie and Ridzuana, who noted the respective duration of their individually set soaking times with respect to their subject matter of choice for maximum effect, the researcher also discovered that the soaking time of sablot paste to produce stronger binding capability is three (3) days.

\section{Acknowledgment}

The author is deeply grateful to Dr. Edelyn Cadorna, Director, Research and Statistical Assistance Center (RSAC), University of Northern Philippines, Vigan City, for extending her technical expertise in the statistical analysis of this study.

\section{References}

https://www.heritage.org.ph/.

Ann Marie Sullivan, Cultural Heritage \& New Media: A Future for the Past, 15 J. MARSHALL REV. INTELL. PROP. L. 604 (2016) https://repository.jmls.edu/cgi/viewconten t.cgi? article $=1392 \&$ context $=$ ripl

Szczepanowska, Hanna M.. 2013. Conservation of cultural heritage: key principles and approaches. Routledge. ISBN 978-0415674744.

Chapin, F. Stuart III, Gary P. Kofinas, and Carl Folke (eds). 2009. Principles of Ecosystem Stewardship: Resilience-Based Natural Resource Management in a Changing World. Springer. ISBN 978-0387730325.

Curtis, Gregory. 2012. The Stewardship of Wealth, + Website: Successful Private Wealth Management for Investors and Their Advisors. Wiley. ISBN 978-1118321867.

Robinson, Joe Sam, M. Sami Walid, Aaron C. M. Barth (Editors). 2012. Toward Healthcare Resource Stewardship: Health Care Issues, Costs, and Access. Nova Science. ISBN 978-1621001829. 
National Academy of Sciences Committee on Ensuring the Utility and Integrity of Research Data in a Digital Age. 2009. Ensuring the Integrity, Accessibility, and Stewardship of Research Data in the Digital Age. National Academies Press. ISBN 9780309147828.

Van Dyke, Fred. 2008. Conservation Biology: Foundations, Concepts, Applications (2nd Edition). Springer. pp 3948. ISBN 978-1402068904.

Jeannet, Jean-Pierre \& Hein Schreuder. 2015, From Coal to Biotech: The transformation of DSM with business school support, Springer. pp 295 -296. ISBN $9783662462980 \quad$ International Standardization for Organizations (ISO 20121)

American Institute for Conservation of Historic and Artistic Works (AIC) - Code of Ethics. Conservation-us.org. Retrieved on 2012-06-29

ICOM-CC International Council of Museums Committee for Conservation

Muñoz-Viñas, Salvador,Contemporary Theory of Conservation. London: Elsevier/Butterworth Heinemann,2005, p. 185.

Ruså-Lie, André, The effects of varying soaking times at two hardening temperatures on material properties and morphology for the martensitic ferritic steel S165M, University of Stavanger, Norway, Published on June 11, 2015 https://brage.bibsys.no/xmlui/handle/11250/ $\underline{301582}$

Norma Esguerra, Sablot (Litsea glutinosa), Lour Rob., A Symbol of Ilocano Ingenuity in Construction, Phil E-journal, (UNP Research Journal, Vol 22, No 1, 2013)

Alfredo Rabena, Propagation Techniques of Endangered Sablot (Litsea glutinosa) Lour. C.B. Rob, Phil E-journal, (JPAIR Multidisciplinary Research Journal, Vol 5, No. 1, 2010)

In Vitro Propagation of Litsea glutinosa (Lour) C.B. Robinson - An Endangered

Medicinal Tree in Madhya Pradesh, India by S.K.Tiwari, G. Krishnamurthy, M.P. Goswami, Amit Pandey and P.K. Singhal

International Journal of Current Research in Biosciences and Plant Biology,
ISSN: 2349-8080 Volume 2 Number 12 (December-2015)

Mancielito S. Tacadena, "Sablot The Tree that Preserved the Old Houses" https://aichannel.wordpress.com/2010/11/21 /sablot-the-tree-that-preserved-the-oldhouses/

Benny Tuazon, "Native Trees

Deserve a Visit

http://www.manilaspeak.com/commentary/n ative-trees-deserve-a-visit, February 25, 2014

https://en.wikipedia.org/wiki/Conservation -restoration of cultural heritage https://tawidnewsmag.com/ https://rainforestrestorationinitiative. wordpress.com/2017/01/25/sablot/ puso.html http://www.stuartxchange.org/Puso-

https://www.pinterest.co.uk/nitoteves /philippine-native-trees/?autologin=true

Vigan City Museum Interviews with senior citizens and elderly

Interview with Msgr. Roque Reyes, Parish Priest of St. Paul Parish, Vigan City, Ilocos Sur and Archdiocesan Curator of Nueva Segovia

TuturLussetyowati, "Preservation and Conservation through Cultural Heritage Tourism. Case Study: Musi Riverside Palembang" published inProcedia - Social and Behavioral Sciences, Volume 184, May 2015, pp 401-406, Elsevier, open access http://www.regionalstudies.org/uploads/net works/documents/tourism-regionaldevelopment-and-public-policy/gunlu.pdf

Assist. Prof. Dr. Ebru Günlü Research Assist. Kamil Yağcı, Prof. Dr. İge Prnar "Preserving Cultural Heritage and Possible Impacts onRegional Development: Case Of İzmir"

Marilena Alivizatou,Intangible Heritage and the Museum: New Perspectives on Cultural Preservation, Routledge, Taylor and Francis Group, 2 Park Square, Milton Park, Abingdon OX 14 4RN, 711 Third Avenue, New York NY 10017 USA http://www.getty.edu/conservation/publicati ons_resources/pdf_publications/pdf/heritage _values_vl.pdf

Alternatives ToPortland Cement https://knowledgepoint.org/upfiles/1427893 $\underline{6733462015 . p d f}$

Jaime SK Yeung, "Alternative Binders for Concrete Other Than Cement". 
Hong Kong Concrete Institute.Hong Kong Concrete Institute www.hongkongci.org

Li X, Li Y, Zhong Z, Wang D, Ratto JA, Sheng K, Sun XS, Mechanical And Water Soaking Properties Of Medium Density Fiberboard With Wood Fiber And Soybean Protein Adhesive,Bioresour Technol. 2009 Jul;100(14):3556-62.doi: 10.1016/j.biortech.2009.02.048. Epub 2009 Mar28.https://www.ncbi.nlm.nih.gov/pubme d/19329303

Kunikazu Ueno, 2012 Survey Report on the Protection of Cultural Heritage in the Republic of the Philippines, Tokyo, Japan, Report on International Cooperation Japan Consortium in Cultural Heritage

F.I. dela Paz, "Architecture as Artifact: The Meaning and Measure of Built Heritage in the Philippines; A Literature Review of Recent and Current Studies on Heritage Conservation in the Philippine Setting

M.J.M. Ridzuana,*, M.S. Abdul Majida, , M. Afendia,, K. Azduwinb, S.N. Aqmariah, Kanafiaha, and Y. Dan-mallama, "The Effects of the Alkaline Treatment's Soaking Exposure on theTensile Strength Of Napier Fibre,"2351-9789 (C) 2015 The Authors. Published by Elsevier B.V. This is an open access article under the CC BY-NCND license (https://www.sciencedirect.com/) Philippines Heritage Conservation Council

Philippine Cultural Heritage Act of 2009

\section{Biography}

\section{Norma Esguerra}

Doctor of Public Administration, 2006, Master of Engineering Management, major in Construction Management, 1997, Master of Arts in Mathematics Education, 1990, Bachelor of Science in Civil Engineering, 1979. Previous employment: Associate Civil Engineer to Senior Civil Engineer at the Department of Public Works and Highways (January 1980- May 1983) while teaching on part time basis at the University of Northern Philippines. Full-time instructor since June 1983. Rose from the ranks from Instructor 1 to Professor 6. Has published researches in the UNP Research Journal and Philippine Engineering Journal, UP Diliman,, Academic Excellence Award (2006), 2012 Staff Writer, UNP CGAD Journal, LGU-Sto. Domingo Arangkada Awardee on Education, Most Outstanding Engineer Mentor in 2011, Best Paper Presentation for Extension Projects for Socio-Economic Category "Livelihood and Productivity Program: Development of Metalcraft Enterprises in the University of Northern Philippines by the Philippine Association of Extension Projects Implementation at Banga, Aklan in 2010, 3rd Prize, Infrastructure Category "Utilization of Research and Development Technology in Organic Agriculture: The UNP Experience at Banga, Aklan in 2010, $3^{\text {rd }}$ Best Scientific Paper in the 2008 Dr. Edgar Padilla Search for the Best Scientific Paper (Regional), Prototyping of a Mechanized Bagoong Squeezer, published one book "Construction Management", ISBN-978-971-0578-00-9, patented aFish Paste Bagoong Squeezerwith Utility Model Registration No. 02-2010-000200 granted last May 12, 2014 and Refrigerant Recycling and Recovery Machinewith Utility Model Application No. 2/2016/000196, filed on April 14, 2016, granted three (3) externally funded research grants from the Department of Science and Technology, published 20 research outputs, Member, Philippine Institute of Civil Engineers, Specialist in Construction Management Engineering,National Accreditor, Accrediting Agency for Chartered Colleges and Universities of the Philippines (AACCUP), Member, Regional/Provincial Pool of Productivity and Quality Specialists in Region 1, Member, GADPool, UNP Center for Gender and Development, Member, University National Budget Circular (NBC) 461 Review Committee for faculty evaluation and promotion 
